\title{
PEMBERDAYAAN KADER JUMANTIK DALAM PEMBERANTASAN DEMAM BERDARAH DENGUE DI KECAMATAN PONDOK KELAPA KABUPATEN BENGKULU TENGAH
}

\author{
Agung Riyadi ${ }^{1}$, Andriana Marwanto ${ }^{2 *}$, S. Pardosi ${ }^{3}$, Septiyanti ${ }^{4}$, Sahran $^{5}$, \\ Hendri Heriyanto ${ }^{6}$ \\ ${ }^{1-6}$ Poltekkes Kemenkes Bengkulu \\ Email:andrian.marwanto@gmail.com
}

Disubmit: 14 Juli 2021

Diterima: 23 Juli 2022

DOI: https://doi.org/10.33024/jkpm.v5i2.4455

\begin{abstract}
ABSTRAK
Angka kejadian Kasus DBD di 10 Kabupaten/Kota propinsi Bengkulu meningkat setiap tahun. Pada tahun 2018 sebanyak 1.415 kasus dengan angka kematian 12 orang dan pada tahun 2019 sebanyak 1.320 kasus dengan angka kematian 11 orang. Wilayah kecamatan Pondok Kelapa angka kejadian DBD pada tahun 2019 adalah 10 kasus. Upaya pengendalian DBD ditekankan pada upaya pencegahan melalui pemberdayaan dan peran serta masyarakat yaitu gerakan Pemberantasan Sarang Nyamuk (PSN) dan memperkuat kapasitas SDM. Tujuan dari Pengabdian Masyarakat ini adalah untuk meningkatkan pengetahuan dan keterampilan dalam pencegahan penyakit DBD yang dipusatkan di Puskesmas Pekik Nyaring Bengkulu Tengah. Metode yang dilakukan dalam kegiatan pengabdian masyarakat ini adalah dengan memberikan pemberdayaan masyarakat tentang pemanfaatan pencegahan DBD, Survey Jentik dan Penanaman lavender.Hasil kegiatan pengabdian masyarakat ini adalah para peserta kegiatan mampu melakukan survey jentik dan budidaya lavender. Untuk keberlanjutan kegiatan ini diharapkan kader jumantik melakukan survey jentik secara berkelanjutan dan membagikan tanaman hasil budidaya ke seluruh masyarakat.
\end{abstract}

Kata Kunci: Survey jentik, DBD, tanaman lavender

\section{BSTRACT}

The incidence of dengue cases in 10 districts/cities of Bengkulu province is increasing every year. In 2018 there were 1,415 cases with 12 deaths and in 2019 there were 1,320 cases with 11 deaths. In the Pondok Kelapa sub-district, the incidence of dengue fever in 2019 was 10 cases. Efforts to control DHF are emphasized on prevention efforts through empowerment and community participation, namely the Mosquito Nest Eradication (PSN) movement and strengthening human resource capacity. The purpose of this Community Service is to increase knowledge and skills in the prevention of dengue disease which is centered at the Pekik Nyaring Health Center Bengkulu Tengah. The method used in this community service activity is to provide community empowerment regarding the use of dengue prevention, larvae survey and lavender planting. For the sustainability of this activity, it is hoped that the jumantik cadres will conduct a larva survey on an ongoing basis and distribute cultivated plants to the entire community.

Keywords: larva survey, DHF, lavender plant 


\section{PENDAHULUAN}

Pada tahun 2017 kasus DBD di Indonesia sebanyak 68.407 kasus dengan angka kematian 493 orang dan pada tahun 2018 menyebutkan kasus DBD di Indonesia sebanyak 65.602 kasus dengan angka kematian 467 orang (Kementerian Kesehatan RI, 2019). Angka kesakitan DBD untuk provinsi Bengkulu pada urutan ke 3 tertinggi dari 34 provinsi. Angka kesakitan DBD provinsi Bengkulu mengalami kenaikan 2 kali lipat dibandingkan 2017 yaitu 31,95 menjadi 72,28 per 100.000 penduduk, kenaikan angka kesakitan tersebut perlu mendapatkan perhatian khusus (Kemenkes RI, 2019).

Angka kejadian Kasus DBD di 10 Kabupaten/Kota propinsi Bengkulu meningkat setiap tahun. Tahun 2017 terdapat sebanyak 618 kasus DBD dengan angka kematian 5 orang, pada tahun 2018 sebanyak 1.415 kasus dengan angka kematian 12 orang dan pada tahun 2019 sebanyak 1.320 kasus dengan angka kematian 11 orang (Dinkes Provinsi Bengkulu, 2019). Berdasarkan hasil wawancara dengan petugas kesehatan Puskesmas Pekik nyaring yang sebagian besar wilayah kerjanya ada di kecamatan Pondok Kelapa angka kejadian DBD pada tahun 2019 adalah 10 kasus. Tahun 2020 diperkirakan terjadi peningkatan kejadian yang sangat signifikan karena pada bulan januari 2020 telah terjadi 18 kasus. (Profil Puskesmas Pekik Nyaring, 2018)

Setiap terjadi kejadian kasus DBD, masyarakat di kecamatan Pondok kelapa biasanya hanya mengandalkan petugas kesehatan melakukan pemberantasan nyamuk demam berdarah dengan cara fogging. Kegiatan fogging tidak efektif untuk mencegah penyakit DBD karena hanya membunuh nyamuk dewasa sementara jentik nyamuk tetap berkembang bila tempat perindukannya tidak dibersihkan. Nyamuk Aedes aegypti akan berkembang biak dengan cepat pada lingkungan yang banyak genangan air dan sampah terutama di musim penghujan. Rumah warga masih banyak terdapat kaleng bekas, batok kelapa dan bak bekas penampungan air atau bekas kolam yang tidak dipakai lagi sehingga menjadi tempat berkembangbiaknya nyamuk. (Yudhastuti R, Vidiyani A, 2015)

Upaya pengendalian DBD ditekankan pada upaya pencegahan melalui pemberdayaan dan peran serta masyarakat yaitu gerakan Pemberantasan Sarang Nyamuk (PSN) dan memperkuat kapasitas SDM. Oleh karena itu peran kader kesehatan perlu terus ditingkatkan untuk melakukan pemantauan, pemeriksaan dan pemberantasan jentik, termasuk juga pengetahuan dasar tentang penyakit DBD dan upaya pencegahannya. Salah satu cara yang lebih ramah lingkungan adalah manfaatkan tanaman anti nyamuk (insektisida hidup pengusir nyamuk). Tanaman hidup pengusir nyamuk adalah jenis tanaman yang dalam kondisi hidup mampu menghalau nyamuk. Artinya tanaman ini tidak perlu diolah terlebih dahulu. Kemampuan jenis tanaman ini sebagai pengusir nyamuk bisa dianggap istimewa. Penyebabnya adalah bau menyengat yang keluar dari tanaman ini. Tanaman yang dapat digunakan untuk pengusir nyamuk diantaranya adalah lavender, bunga tahi ayam, kenanga, kemangi, serai wangi dan selasi. (Ruharno Z dan Rasuane N, 2016)

Berdasarkan uraian di atas, perlu dilakukan upaya untuk menggerakan masyarakat hidup sehat dan aktif melakukan pencegahan penyakit DBD melalui pemberdayaan kader jumantik Puskesmas Pekik Nyaring 


\section{MASALAH}

Permasalahan memilih tempat kegiatan pengabdian masyarakat adalah angka kejadian DBD di Kecamatan Pondok Kelapa terjadi peningkatan kejadian yang sangat signifikan dan pada bulan januari 2020 telah terjadi 18 kasus. Selain itu, sebagian besar warga di Kecamatan Pondok Kelapa belum menerapkan perilaku hidup sehat dan belum aktif untuk melakukan tindakan pencegahan terjadinya penyakit demam berdarah. Rumah warga masih banyak terdapat kaleng bekas, batok kelapa dan bak bekas penampungan air atau bekas kolam yang tidak dipakai lagi sehingga menjadi tempat berkembangbiaknya nyamuk. Sehingga kami melakukan upaya pemberdayaan kader jumantik untuk meningkatkan pengetahuan dan keterampilan dalam pencegahan penyakit DBD yang dipusatkan di Puskesmas Pekik Nyaring Bengkulu Tengah
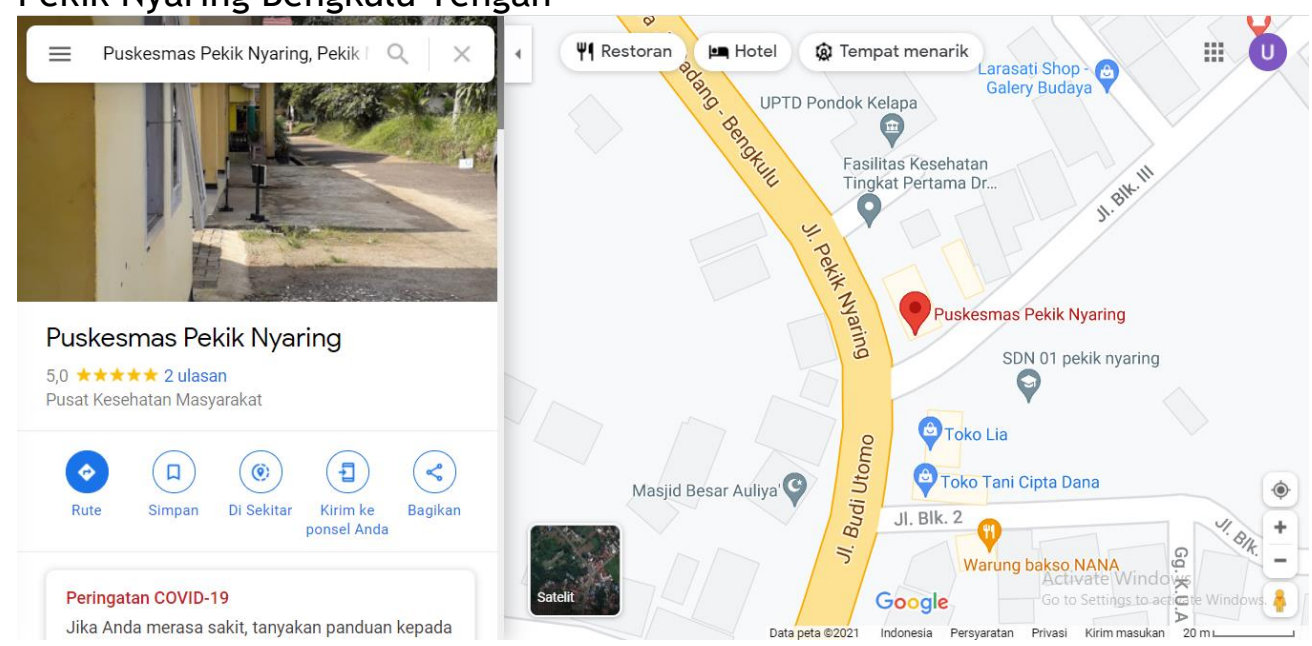

Gambar 1 Peta Lokasi Kegiatan Pengabdian Kepada Masyarakat

\section{METODE}

a. Tahap Persiapan

Dalam rangka pelaksanaan kegiatan pengabmas ini team melakukan langkah -langkah persiapan yaitu

1) Mengumpulkan data-data yang terkait dengan keadaan wilayah yang akan di lakasanakan pengabdian masyarakat

2) Koordinasi dengan pegawai puskesmas dan pegawai kantor camat kecamatan Pondok Kelapa.

3) Menyimpulkan masalah apa yang muncul dan potensial diatasi dengan pengabdian masyarakat

4) Menentukan sasaran dilaksanakannya pengabdian masyarakat.

5) Persiapan media edukasi berupa booklet, dan leaflet, pembibitan tanaman anti nyamuk.

6) Perekrutan kader jumantik dari masing - masing desa yang ada di Kecamatan Pondok Kelapa. Dengan sasaran kader 20 orang.

b. Tahap Pelaksanaan

Kegiatan pengabmas dilaksanakan dari bulan Februari sampai dengan November 2020. Dalam melaksanakan kegiatan Program Kemitraan wilayah ini, tim pelaksana membagi kegiatan dalam pembimbingan dan pendampingan. Metode yang digunakan adalah; pertama, health education yang digunakan untuk memberi penerangan 
kepada kader dan masyarakat agar dapat bekerja sama dan mencapai apa yang diinginkan dan mengatasi demam berdarah. Kedua, Prevention, yakni dengan melakukan berbagai tindakan untuk menghindari terjadinya berbagai masalah kesehatan yang mengancam pribadi dan orang disekelilingnya terutama dalam mencegah terjadinya demam berdarah dimasyarakat dengan menjaga kebersihan lingkungan dan penanaman pohon anti nyamuk.

Dari beberapa permasalahan yang muncul pada mitra, maka tim membuat rincian tahapan pelaksanaan Program Kemitraan wilayah sebagai berikut :

1) Edukasi Pemberantasan Sarang Nyamuk (PSN), 3M Plus dengan Gerakan satu rumah satu (Juru Pemantau Jentik) Jumantik

2) Simulasi pemantauan jentik kerumah warga.

3) Pembagian tanaman anti nyamuk dan simulasi pembibitan tanaman.

c. Evaluasi

Untuk menjaga keberlanjutan program, maka Tim Pengusul melakukan pendampingan dengan melibatkan berbagai pihak yang berwenang, Kepala Puskesmas, Kepala Desa, kepala Dusun, ketua RT/RW, Tokoh Masyarakat, dan kader jumantik. Pada tahap ini akan dilihat kondisi di tempat sasaran apakah sudah berhasil atau belum program yang telah dilaksanakan. Dalam kegiatan ini, para warga akan diberi booklet, diharapkan setelah mendapatkan materi tersebut bisa dijadikan alat untuk menularkan ilmunya. Dilingkungan pun juga akan dipasang poster tentang DBD. Para warga juga akan diberi alat pembersih bak air, sehingga setelah kegiatan ini masyarakat tetap melaksanakan program 3M Plus ini.

Kegiatan evaluasi dalam pelaksanaan kegiatan pengabdian masyarakat meliputi:

1) Evaluasi input

Teridentifikasinya jumlah dan nama kader jumantik, tersedianya media edukasi yang akan digunakan selama kegiatan pengabmas, dihasilkannya komitmen dukungan pelaksanaan pengabmas.

2) Evaluasi proses

Kader akan mengikuti kegiatan pelatihan tentang penanganan demam berdarah, melaksanakan survey jentik dan melakukan tindakan pencegahan demam berdarah bersama masyarakat.

3) Evaluasi output

a) Terjadi peningkatan pengetahuan, dan keterampilan kader jumantik dalam menangani demam berdarah dan tindakan pencegahannya..

b) Terlaksananya kegiatan pendampingan oleh kader pada keluarga dalam melakukan tindakan pencegahan demam berdarah melalui $3 \mathrm{M}$ dan penanaman tanamam anti nyamuk.

c) Terjadi penurunan prosentasi angka jentik nyamuk di masyarakat. 


\section{HASIL DAN PEMBAHASAN}

Hasil kegiatan pengabdian masyarakat yang dilaksanakan di desa pekik nyaring kecamatan pondok kelapa adalah sebagai berikut:

1. Pembentukan kelompok kader

Berdasarkan hasil pelatihan yang dilakukan oleh tim pengabmas jumlah kader jumantik terlatih di Puskesmas Pekik Nyaring mengalami peningkatan dan telah dibentuk grup Whatsapp jumantik untuk memudahkan koordinasi dan monitoring evaluasi oleh pihak puskesmas.
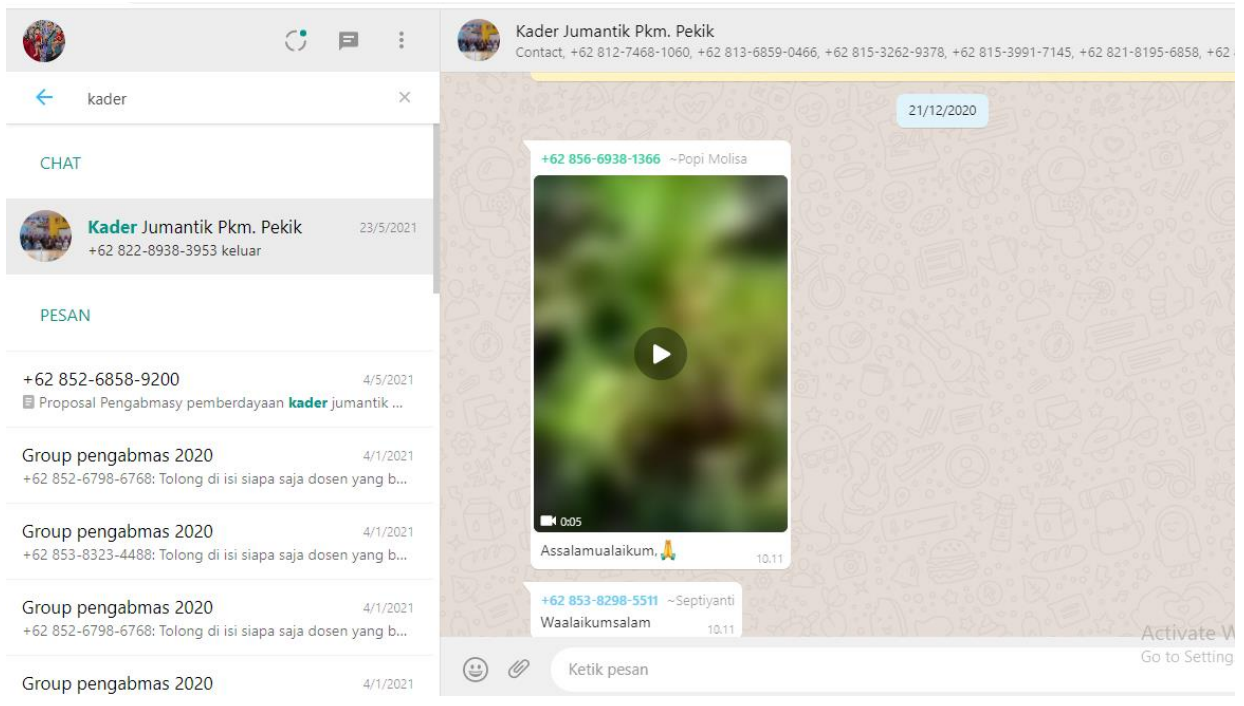

Gambar 2. Grup WA Kader Jumantik Puskesmas Pekik Nyaring

2. Pengetahuan kader tentang upaya pencegahan penyakit DBD

Pada tanggal 5 September 2020 dilakukan pelatihan bagi Kader jumantik tentang upaya pencegahan penyakit DBD. Pada kegiatan tersebut selain diikuti oleh kader juamntik lama dilatih juga beberapa kader jumantik yang baru dengan jumlah total peserta 24 orang. Pada pelatihan tersebut juga dibagikan buku saku dan leaflet tentang upaya pencegahan penyakit demam berdarah dengue.

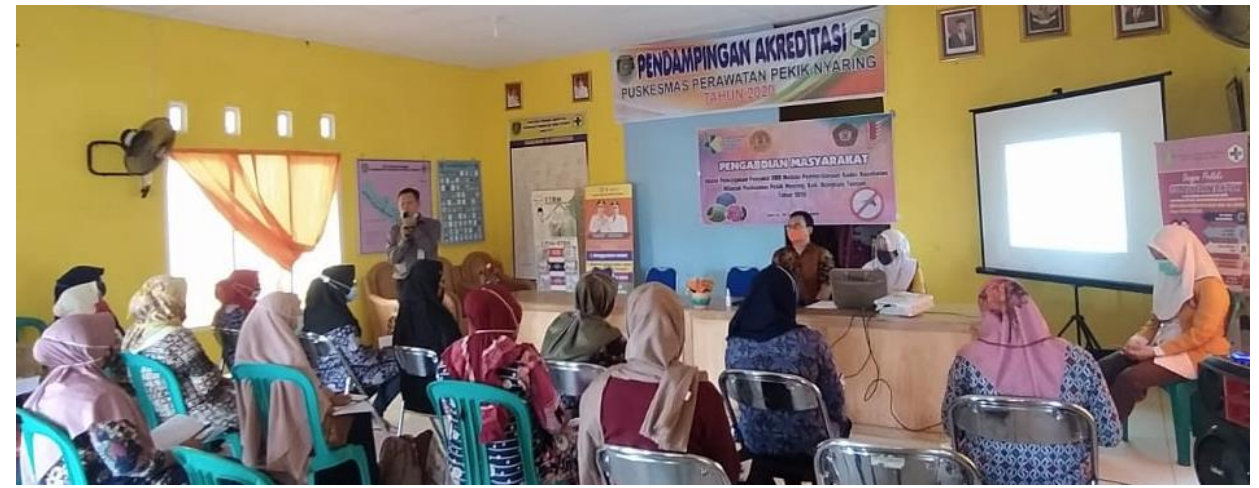

Gambar 3. Penyampaian Materi untuk meningkatkan pengetahuan Kader Jumantik tentang Pencegahan DBD 
Berdasarkan hasil pelatihan jumantik yang dilaksanakan menunjukkan rata-rata skore pengetahuan pretest adalah 59,00 dengan standar deviasi 13.727 sedangkan rata-rata skore post test adalah 81,00 dengan standar deviasi 12.937. Hasil uji T dependen menunjukkan ada perbedaan rata-rata skore pengetahuan sebelum dan sesudah pelatihan kader jumantik ( $p: 0,000$ ). Hasil analisis tersebut di atas menujukkan ada peningkatan rata-rata skore pengetahuan pengetahuan kader Jumantik tentang upaya pencegahan penyakit DBD sebelum dan sesudah diberikan kegiatan pelatihan, artinya ada peningkatan pengetahuan kadersetelah mengikuti pelatihan tentang upaya pencegahan penyakit DBD.

3. Keterampilan kader dalam melakukan survei jentik

Pada tanggal 10 September 2020 dilaksanakannya kegiatan survei jentik di wilayah puskesmas Pekik Nyaring yang diikuti oleh seluruh tim pengabmas, mahasiswa dan kader. Pada kegiatan tersebut dilakukan pemberdayaan kader yang sudah dilatih untuk survei awal jumlah jentik di salah satu desa yang paling banyak kasus DBD.

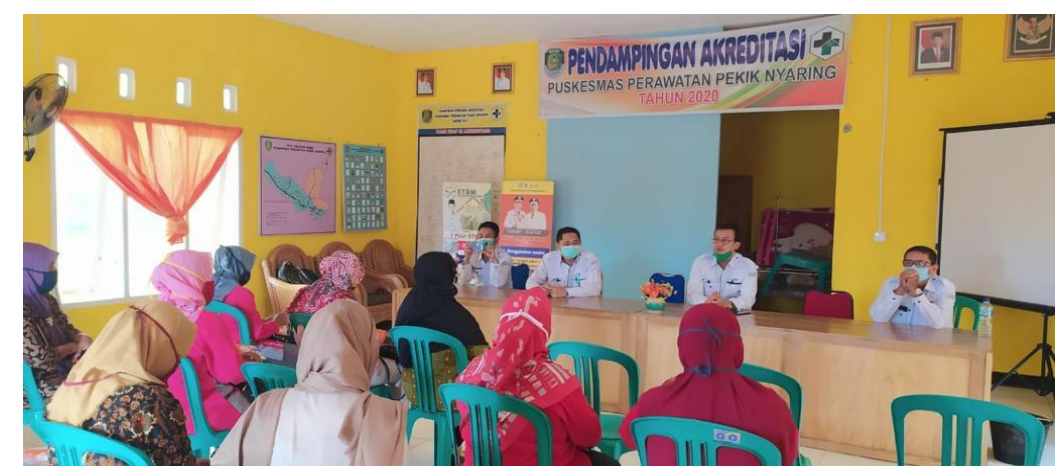

Gambar 4. Persiapan kegiatan Survey Jentik

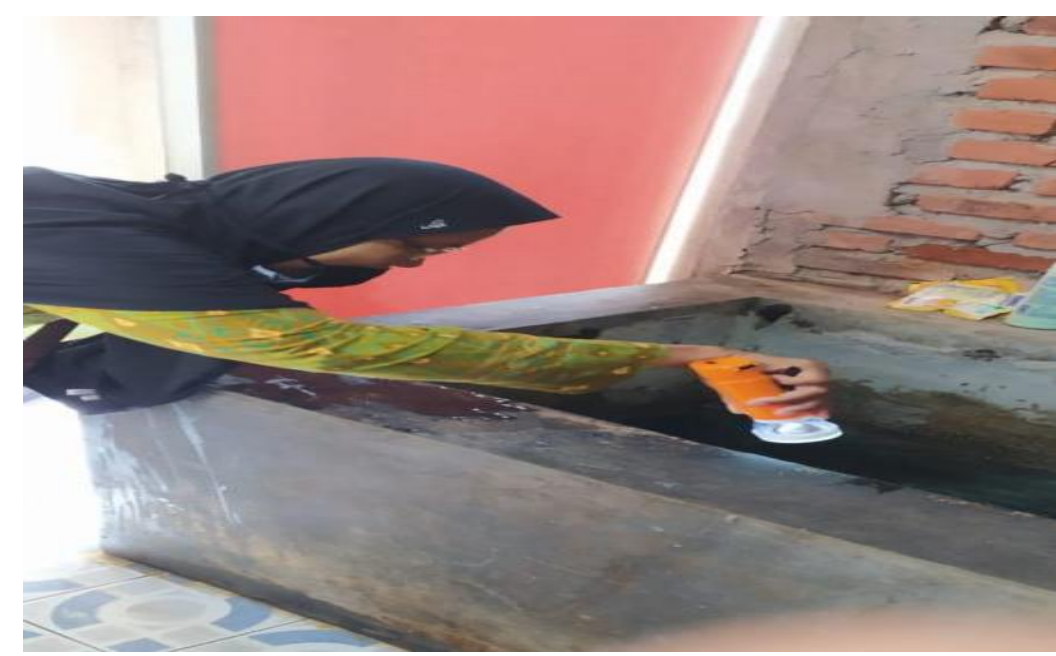

Gambar 5. Kegiatan Survey Jentik yang dilakukan oleh kader Jumantik 
Hasil observasi tim terhadap kemampuan kader dalam melakukan survei jentik menunjukkan $75 \%$ kader sudah dapat melakukan survei secara mandiri dan $25 \%$ masih membutuhkan pendampingan tim dalam melakukan survei jentik.

4. Tanaman anti nyamuk

Pada tanggal 21 September 2020 tim melakukan pendistribusian tanaman anti nyamuk yaitu tanaman lavender, serai wangi dan yudistira sebanyak 200 polibag kepada kader yang telah dilatih. Tanaman tersebut selanjutnya dilakukan pembudidayaan oleh kader untuk kemudian dibagikan ke masyarakat desa pekik nyaring terutama yang banyak terdapat nyamuk DBD.

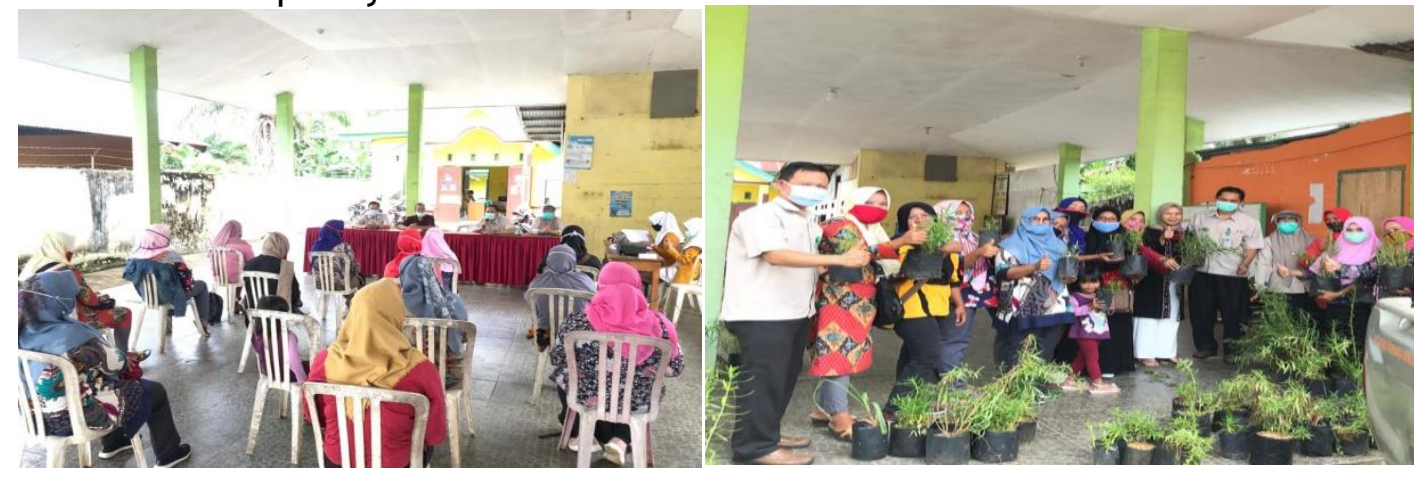

Gambar 6. Pembudidayaan dan pendistribusian tanaman lavender

Hasil survei terhadap pembudidayaan tanaman lavender oleh kader jumantik menunjukkan dari 200 polibag tanaman anti nyamuk yang dibagikan telah berhasil dikembangkan menjadi 385 polibag. Jumlah ini mencapai hampir $100 \%$ pembudidayaannya dikarenakan musim hujan yang sangat membantu mempercepat proses pertumbuhan lavender.

\section{KESIMPULAN}

Hasil kegiatan pengabdian masyarakat di desa pekik nyaring kecamatan pondok kelapa dapat disimpulkan sebagai berikut:

1. Terbentuknya kelompok kader jumantik di Puskesmas Pekik Nyaring.

2. Terjadi peningkatan pengetahuan kader juamantik dalam upaya pencegahan penyakit DBD.

3. Terjadi peningkatan keterampilan kader jumantik dalam melakukan survey jentik dan perhitungan indikatornya

4. Telah terlaksananya pembudidayaan dan pendistribusian tanaman anti nyamuk di desa pekik nyaring kecamatan pondok kelapa.

\section{DAFTAR PUSTAKA}

Dinas Kesehatan Provinsi Bengkulu. (2019). Profil Kesehatan Provinsi Bengkulu. Bengkulu: Dinas Kesehatan Provinsi Bengkulu.

Fridolina Mau dan Ira I.P. Bule Sopi. (2014)." Demam Berdarah Dengue Dan Transmisi Transovarial Virus Dengue Pada Aedes Spp." Jurnal Penyakit Bersumber Binatang, Vol. 2 No. 1. 
Kementerian Kesehatan RI. (2010). Buletin Jendela Epidemiologi Demam Berdarah Dengue. Jakarta: Pusat Data dan Surveilans Epidemiologi Kemenkes RI.

Kementerian Kesehatan RI. (2019). Profil Kesehatan Indonesia. Jakarta: Kementerian Kesehatan RI.

Koban AW. (2010). Kebijakan Pemberantasan Wabah Penyakit; KLB Demam Berdarah Dengue (KLB DBD). Jakarta: Bappenas.

Puskesmas Pekik Nyaring. (2018). “Profil Puskesmas Pekik Nyaring 2018 “

Ruharno Z dan Rasuane N. (2016). Inventarisasi Tanaman Yang Berpotensi Sebagai Bioinsektisida Nyamuk Aedes Aegyptii Di Kota Metro Provinsi Lampung. Lampung: Jurnal Bioedukasi.

WHO. (2019). "WHO Region of the Americas records highest number of dengue cases in history; cases spike in other regions" diakses dari https://www.who.int/news-room pada 10 pebruari 2021.

Widiyono, (2008). Penyakit Tropis Epidemiologi, Penularan, Pencegahan, dan Pemberantasannya. Jakarta: Erlangga.

Yudhastuti R, Vidiyani A. (2015). Hubungan Kondisi Lingkungan, Kontainer, Dan Perilaku Masyarakat Dengan Keberadaan Jentik Nyamuk Aedes Aegypti Di Daerah Endemis Demam Berdarah Dengue Surabaya. J Kesehatan Lingkungan. 2005;1(2):17083. 